\title{
COPING STRESS SINGLE MOTHER DI KOTA JAMBI
}

\section{Anggita Wahyu Hapsari*, Siti Urbayatun}

\section{Magister Psikologi Sains, Universitas Ahmad Dahlan Yogyakarta}

\section{Email Corresponding:} anggitawahyuhapsari@gmail.com

Page : $11-16$

Kata Kunci : emotion-focused coping, single mother, konflik, koping stres, wanita

Keywords: emotion-focused coping, single mother, conflict, coping stress, women

Published by:

Tadulako University,

Managed by Faculty of Medicine.

Email: healthytadulako@gmail.com

Phone (WA): +6285242303103

Address:

Jalan Soekarno Hatta Km. 9. City of Palu, Central Sulawesi, Indonesia

\section{ABSTRAK}

Perubahan yang terjadi akibat perceraian dalam rumah tangga membuat munculnya ibu tunggal. Terjadinya perubahan status berdampak secara psikis, ekonomi dan sosial. Wanita yang ditinggalkan karena perceraian harus mampu menjalankan multi peran dalam keluarga. Tanggung jawab yang dipikul seorang single mother dapat menimbulkan konflik internal apabila individu tidak dapat menyeimbangkan perann. Pada kondisi ini perlu adanya upaya untuk membantu individu mengatasi maupun mengurangi emosi negatif dalam dirinya yang disebut coping stress. Tujuan penelitian untuk mengetahui gambaran bentukbentuk coping stress single mother di Kota Jambi dan faktor-faktor yang mempengaruhi coping stress single mother di Kota Jambi. Partisipan dalam penelitian ialah wanita berusia 30-40 tahun, telah bercerai minimal 2 tahun, bekerja di instansi pemerintahan, memiliki anak dibawah umur dan berdomisili di Kota Jambi. Metode penelitian yang digunakan adalah kualitatif dengan pendekatan fenomenologi. Teknik pengumpulan data yang digunakan adalah wawancara semiterstruktur. Hasil penelitian menunjukkan partisipan menggunakan emotion-focused coping untuk menghadapi permasalahannya dan terdapat lima faktor yang mempengaruhi coping stress pada kelima partisipan yaitu kesehatan dan energi serta keyakinan diri yang positif. Hasil temuan baru dalam penelitian ini yaitu emosinal, religiusitas, prioritas anak dan kemandirian. Kesimpulannya hasil penelitian menunjukkan kelima partisipan mampu mengatasi stres dengan menggunakan coping stress yang digunakan sehingga dapat menjalani kehidupannya kembali.

ABSTRACT
Changes that occur due to divorce in the household make the emergence of
single mothers. Changes in status have a psychological, economic and social
impact. Women left by divorce must be able to carry out multiple roles in the
family. The responsibilities of a single mother can lead to internal conflicts if the
individual cannot balance roles. In this condition, efforts need to be made to help
individuals overcome or reduce negative emotions in themselves which is called
coping stress. The purpose of the study was to describe the forms of single
mother stress coping in Jambi City and the factors that influence single mother
stress coping in Jambi City. Participants in the study were women aged $30-40$
years, had been divorced for at least 2 years, worked in government agencies,
had minors and lived in Jambi City. The research method used is qualitative with
a phenomenological approach. The data collection technique used is semi-
structured interview. The results showed that participants used emotion-focused
coping to deal with their problems and there were five factors that influenced
stress coping in the five participants, namely health and energy and positive self-
confidence. The new findings in this study are emotional, religiosity, children's
priorities and independence. In conclusion, the results of the study showed that
the five participants were able to cope with stress by using the stress coping used
so that they could live their lives again.

\section{PENDAHULUAN}

Menjadi orang tua tunggal bagi anak merupakan fenomena yang sudah cukup sering dijumpai. Barus (2017) berpendapat bahwa perceraian ini sendiri membawa dampak dalam tanggung jawab individu ${ }^{1}$. Selain itu, Anggraheni (2016) menyatakan adanya perubahan status single mother membawa pengaruh dalam kehidupan 
ekonomi, sosial maupun psikologi individu yang mengalami ${ }^{2}$. Pada pembahasan kali ini, peneliti tidak membahas mengenai single parent melainkan single mother yang terjadi pada wanita yang telah bercerai dan menjadi orang tua tunggal bagi anak-anaknya.

Menurut Qaimi (2003) Single mother adalah suatu keadaan dimana seorang ibu menduduki dua jabatan sekaligus, yaitu sebagai ibu yang merupakan jabatan alamiah serta sebagai ayah ${ }^{3}$. Kasus orang tua tinggal sendiri akibat dari perceraian sangat banyak terjadi hampir diseluruh negara termasuk Indonesia ${ }^{3}$.

Berdasarkan Data Statistik Kota Jambi (www.jambikota.bps.go.id) selama tiga tahun terakhir menunjukkan adanya peningkatan jumlah perceraian di Kota Jambi. Berdasarkan wawancara dengan salah staff Badan Pusat Statistik bahwa perceraian hampir setiap tahun meningkat karena banyaknya wanita yang melakukan gugatan akibat telah memiliki pekerjaan tetap ( $R K$-diwawancarai 09 Maret 2021, 10.21 WIB, BPS Kota Jambi) $)^{3}$.

Tabel 1.1 Jumlah Pernikahan dan Perceraian 20182020

\begin{tabular}{ccc}
\hline Tahun & $\begin{array}{c}\text { Jumlah } \\
\text { Pernikahan }\end{array}$ & $\begin{array}{c}\text { Jumlah } \\
\text { Perceraian }\end{array}$ \\
\hline 2018 & 4.177 & 989 \\
2019 & 4.123 & 1.087 \\
2020 & 4.165 & 1.401 \\
\hline Jumlah & 12.465 & 4.878 \\
\hline \multicolumn{2}{c}{ Sumber : Badan Pusat Statistik Kota Jambi 2018-2020 }
\end{tabular}

Di Indonesia, hakim pengadilan cenderung memberikan hak asuh anak kepada ibu terutama bagi anak yang masih dibawah umur ${ }^{4}$. Hal ini sesuai dengan hasil wawancara awal bahwa hak asuh anak dibawah 17 tahun menjadi tanggung jawab ibunya, sementara ayahnya bertanggung jawab untuk tetap menafkahi anaknya (WYdiwawancarai tanggal 03 Februari 2021, pukul 10.57, Rumah partisipan WY).

Dampak perceraian lain yang juga dirasakan adalah rusaknya tatanan sosial, memberikan contoh yang tidak baik bagi pasangan lain, berdampak dengan ekonomi rumah tangga, relasi individu dan sosial antar keluarga bahkan juga psikis anak ${ }^{1}$. Dampak psikologis dari adanya perceraian terhadap anak antara lain takut kurang perhatian dan kasih sayang, menurunnya prestasi disekolah, menjadi anti sosial dan senang menyendiri bahkan dapat menimbulkan depresi mental ${ }^{5}$.

Tuntutan peran ganda yang dijalani single mother dapat memicu timbulnya konflik antara pekerja dan peran sebagai ibu yang dapat menimbulkan stress berkepanjangan bahkan menganggu aktivitas sehari-hari ${ }^{3}$.

Pada dasarnya setiap individu memiliki kemampuan Coping Stress yang berbeda begitu pula yang terjadi pada setiap ibu. Tingkat pendidikan juga turut mempengaruhi bagaimana coping stress dari masing-masing $\mathrm{ibu}^{6}$. Dalam bidang psikologi konsep untuk mengatasi atau menanggulangi stres disebut Strategi coping stress. Menurut Lazarus dan Folkman (1984) Pengelolaan stres yang disebut dengan istilah Coping Stress yaitu proses mengelola tuntutan (baik internal atau eksternal) yang ditafsir sebagai beban karena diluar kemampuan individu?

Lazarus dan Folkman (1984) membagi bentuk coping stress menjadi dua yaitu problem focused coping dan emotion focused coping. Sementara itu, faktor yang mempengaruhi startegi coping stress dibagi menjadi lima yaitu kesehatan dan energi, ketrampilan problem solving, keyakinan yang positif, dukungan sosial dan sumber daya material ${ }^{7}$. Keberhasilan dari strategi coping stress dapat dilihat dari bagaimana individu tersebut menghadapi kembali tekanan serta situasi dan kondisi yang sama ${ }^{8}$.

Dalam penelitian ini yang menjadi fokus utama adalah terkait bagaimana Coping Stress Single Mother di Kota Jambi. Peneliti ingin melakukan penelitian secara lebih mendalam terkait masalah-masalah yang dihadapi serta konflik peran ganda yang dijalani juga faktor faktor yang mempengaruhi strategi coping stress pada single mother tersebut. Tujuan dari penelitian ini adalah untuk mengetahui gambaran bentukbentuk strategi coping stress single mother di Kota Jambi dan mengetahui faktor-faktor yang mempengaruhi strategi coping stress single mother di Kota Jambi.

\section{BAHAN DAN CARA}

Metode penelitian yang digunakan adalah penelitian kualitatif dengan pendekatan fenomenologi. Teknik penelitian yang 
digunakan adalah teknik purposive sampling yaitu teknik pengambilan sampel sumber data dengan adanya pertimbangan tertentu? Karakteristik partiisipan dalam penelitian ialah :

a) Single mother cerai hidup

b) Usia 30-40 tahun

c) Telah bercerai minimal 2 tahun

d) Bekerja di instansi pemerintahan

e) Memiliki anak dibawah umur (0-17 tahun)

f) Berdomisili di Kota Jambi.

Metode pengambilan data yang digunakan dalam penelitian adalah wawancara yang digunakan adalah wawancara semiterstruktur. Wawancara jenis ini adalah wawancara yang termasuk dalam kategori in-depth interview, dengan tujuan untuk menemukan permasalahan secara lebih terbuka dimana pihak yang diajak wawancara diminta pendapat dan ide-idenya.

Pendekatan dalam Analisis data yang digunakan dalam penelitian ini adalah metode analisis isi atau content analysis. Analisis isi merupakan suatu analisis mendalam yang dapat digunakan pada penelitian kualitatif maupun kuantitatif terhadap pesan-pesan menggunakan metode ilmiah dan tidak terbatas pada jenis-jenis variable yang diukur ${ }^{10}$.

Kredibilitas dalam penelitian ini menggunakan Member Check sebagai uji keabsahan data dari penelitian yang akan dilakukan dengan tujuan untuk mengetahui kesesuaian atau kebenaran atas data yang diberikan oleh partisipan. Adapun etika penelitian dalam penelitian ini yaitu lembar persetujuan informed consent, menjamin kerahasiaan data, menjelaskan tentang kegunaan penelitian, menjelaskan tentang apa yang dilakukan dan memberikan reward kepada subjek.

\section{HASIL}

Penelitian ini menghasilkan temuan yang berkaitan dengan topik penelitian, berikut ini profil dari kelima partisipan.
Tabel 1.2 Profil Lima Partisipan

\begin{tabular}{ccccl}
\hline $\begin{array}{c}\text { Inisial } \\
\text { Subjek }\end{array}$ & $\begin{array}{c}\text { Usia } \\
\text { Subjek }\end{array}$ & $\begin{array}{c}\text { Jumlah } \\
\text { Anak }\end{array}$ & $\begin{array}{c}\text { Lama } \\
\text { Bercerai }\end{array}$ & $\begin{array}{c}\text { Alasan } \\
\text { Bercerai }\end{array}$ \\
\hline A & 37 & 1 & $\begin{array}{c}2,5 \\
\text { tahun }\end{array}$ & $\begin{array}{l}\text { Kesenjangan } \\
\text { Pendidikan }\end{array}$ \\
\hline B & 38 & 2 & 3 tahun & Ekonomi \\
\hline C & 38 & 2 & 3 tahun & $\begin{array}{l}\text { Selingkuh, } \\
\text { KDRT }\end{array}$ \\
\hline D & 39 & 3 & 4 tahun & $\begin{array}{l}\text { Ekonomi, } \\
\text { KDRT }\end{array}$ \\
\hline E & 40 & 4 & 5 tahun & $\begin{array}{l}\text { Tidak ada } \\
\text { kecocokan }\end{array}$ \\
\hline
\end{tabular}

Gambaran bentuk-bentuk coping stress single mother di Kota Jambi menunjukkan hasil berikut :

Berdasarkan hasil pengambilan data yang dilakukan dengan menggunakan metode teknik observasi dan wawancara pada kelima partisipan. Hasil temuan yang didapat dalam penelitian adalah sebagai berikut :

1. Problem-focused coping adalah upaya untuk mengatasi stres secara langsung pada sumber stress. Upaya penanggulangan stres yang dilakukan ini memiliki beberapa aspek-aspek diantaranya:

a. Confrontive coping. Kelima partisipan memilih fokus untuk menata kehidupannya baik dari segi pengembangan usaha maupun karir unuk masa depan dirinya dan anakanaknya kelak.

b. Planful Problem Solving.Partisipan C memilih untuk mencari solusi dari masalahmasalah yang ditemuinya dalam kehidupan sebagai single mother.

c. Seeking social support. Dua dari lima partisipan yaitu partisipan A dan C memperoleh dukungan dari lingkungannya baik keluarga maupun sahabat dekat.

2. Emotion-focused coping adalah upaya yang bertujuan untuk meredakan atau mengurangi tekanan emosional atau mengurangi emosi negatif yang ditimbulkan oleh situasi tanpa melakukan usaha mengubah stressor secara langsung. Terdapat 5 aspek dalam coping stress diantaranya :

a. Accepting Responsibility. Empat partisipaan yaitu A,B,C,D memilih untuk melakukan evaluasi, penerimaan serta adanya usaha untuk berdamai dengan masa lalu. 
b. Escape avoidance. Empat partisipan (A,B,C,D) memilih untuk menghindari sumber masalahnya dengan mengurangi kegiatan diluar rumah.

c. Positive Reappraisal. Lima partisipan mengatakan bahwa adanya pengaruh positif yang dirasakan tiap kejadian yang dilaluinya seperti mendekat dengan Tuhan.

d. Distancing. Dua partisipan (C\&E) memilih untuk bersenang-senang dan tidak memperdulikan masalah hingga masalah tersebut selesai dengan sendirinya.

e. Self Control. Lima partisipan memilih untuk menjaga sikap maupun perbuatannya baik dilingkungan kerja maupun rumah.

3. Faktor yang mempengaruhi strategi coping stress

a. Kesehatan dan Energi. Lima partisipan menyatakan bahwa ada pengaruh kesehatan yang dirasakan karena masalah-masalah dalam kesehariannya.

b. Keyakinan diri yang positif. Lima partisipan menyatakan kepercayaan pada Tuhan memiliki pengaruh yang besar dalam membantu penyelesaian masalah.

c. Dukungan Sosial. Dua partisipan A dan C mengaku dukungan sekitar membuatnya lebih baik ketika sedang ada masalah dalam kehidupannya.

d. Emosional. Lima partisipan mudah terbawa emosi negatif seperti kesal.

e. Stigma Lingkungan. Empat partisipan mengatakan dapat perlakuan tidak baik dari lingkungan tempat tinggal maupun kerja.

f. Prioritas Anak. Lima partisipan selalu mengutamakan masa depan serta kebahagiaan anak-anaknya

g. Penyebab Stres. Lima partisipan mengaku penyebab stress antara lain masalah ekonomi, anak, kesehaatan serta pekerjaan

h. Kemandirian. Lima partisipan memiliki penghasilan tetap untuk memenuhi kebutuhan sehari-hari.

i. Pengambilan Keputusan. Lima partisipan memilih untuk melanjutkan kehidupannya dengan menata menjadi lebih baik. j. Religiusitas. Lima partisipan merasakan adanya pengaruh ibadah ketika sedang dalam keterpurukan dalam hidupnya.

k. Tanggung Jawab Mantan Suami Kepada Anak. Lima partisipan mengatakan mantan suami tidak pernah memberikan nafkah maupun berkomunikasi dengan anaknya.

\section{PEMBAHASAN}

Berdasarkan aspek-aspek strategi coping stress dan faktor-faktor yang mempengaruhinya sebagai berikut :

\section{Bentuk-bentuk Strategi Coping Stress}

\section{a. Emotion-focused coping.}

Dalam aspek confrontive coping, para partisipan memilih menata kehidupan untuk masa depan anak-anaknya karena sadar mantan suami sudah tidak dapat diharapkan kembali. Hal ini sejalan dengan penelitian dari Rahayu (2017) yang menyatakan bahwa single mother tidak mau melibatkan sosok mantan suami karena merasa bisa mandiri dan tidak mau menggantungkan hidup anaknya pada mantan suami sehingga mereka lebih menyipakan mental untuk kedepannya ${ }^{11}$.

b. Problem-focused coping.

Pada aspek possitive reappraisal, kelima partisipan mengambil pembelajaran dari tiap masalah yang dihadapinya dan membuatnya lebih berhati-hati dalam pengambilan keputusan serta berusaha ikhlas menjalani kehidupan.

Dan pada aspek self control menunjukkan bahwa kelima partisipan mengatur tindakan maupun perkataan baik saat berada dilingkungan rumah maupun kerja untuk meminimalisir adanya stigma negatif yang diterima. Hal ini sesuai dengan penelitian yang dilakukan oleh Rahayu (2017) bahwa single mother memilih untuk melakukan sosialisasi dengan masyarakat sekitar untuk menumbuhkan rasa percaya diri serta mengurangi labelling yang diberikan masyarakat pada single mother ${ }^{11}$.

\section{Faktor yang mempengaruhi Coping Stress}

a. Kesehatan dan energi. Lima partisipan merasakan pengaruh kesehatan karena 
adanya tekanan tekanan yang dirasakan akibat harus mampu menjalankan dua peran sekaligus di kesehariannya. Hal ini sejalan dengan penelitian yang dilakukan oleh Ulfa dan Fahriza (2019) bahwa stres dapat berpengaruh terhadap kesehatan dengan melepaskan sejumlah hormon dan meningkatkan detak jantung, laju pernapasan stres dapat mengakibatkan sakit kepala dan insomnia dan beresiko hipertensi bahkan gangguan pencernaan ${ }^{12}$.

b. Keyakinan diri yang positif. Lima partisipan mengatakan kedekatan dengan Tuhan serta meningkatnya ibadah membawa pengaruh dalam mempengaruhi coping stress yang dipilihnya untuk mengurangi emosi negatif.

\section{KESIMPULAN DAN SARAN}

\section{A. Kesimpulan}

Berdasarkan hasil temuan penelitian dan pembahasan yang telah diuraian pada bab sebelumnya, maka didapatkan beberapa kesimpulan terkait gambaran bentuk coping stress dan faktor yang mempengaruhi coping stress pada single mother di Kota Jambi sebagai berikut :

1. Kelima partisipan memiliki persamaan pada gambaran bentuk coping stress yaitu confrontive coping, possitive reappraisal dan self control yang berpengaruh dalam coping stress yang dilakukan dalam menghadapi masalahnya.

2. Hasil penelitian menunjukkan bahwa kelima partisipan memiliki dua faktor yang mempengaruhi mereka dalam melakukan coping stress yaitu kesehatan dan energi serta keyakinan diri yang positif.

3. Hasil penelitian menunjukkan kelima partisipan cenderung menggunakan emotion-focused coping untuk menanggulangi stres yang dialaminya dan hal tersebut sesuai dengan teori yang digunakan oleh peneliti yaitu teori Lazzarus (1984) dan kelima partisipan memenuhi 2 dari 5 bentuk emotion-focused coping yaitu possitive reappraisal dan self control.

4. Hasil temuan yaitu Emosional, Religiusitas, Prioritas anak dan Kemandirian juga menjadi gambaran penting dalam melakukan coping stress karena hal ini mampu membuat mereka menghadapi dan mengatasi permasalahan yang mereka alami dalam kehidupan sebagai single mother

\section{B. Saran}

\section{Saran Teoritis}

Bagi peneliti selanjutnya apabila ingin melakukan penelitian dengan metode yang sama diharapkan dapat lebih memahami terkait dinamika psikologi serta disarankan untuk melakukan penelitian dengan sampel yang lebih luas mengenai karakteristik

2. Saran Praktis

Disarankan untuk tiap orang tua yang ada keinginan bercerai, lebih memikirkan bagaimana nasib anak-anaknya serta apabila sudah bercerai diharapkan tetap memberikan yang terbaik dan menjalankan tanggung jawab terhadap anak.

\section{UCAPAN TERIMAKASIH}

Terima kasih peneliti ucapkan yang tak terhingga atas bantuan serta bimbingan dari berbagai pihak dalam membantu penyelesaian tesis ini.

\section{DAFTAR PUSTAKA}

1. Barus KSB. Faktor-Faktor Penyebab Dan Dampak-Dampak Terjadinya Perceraian Di Kota Medan (Studi Kasus di Pengadilan Agama Medan Kelas I-A). Published online 2017. https://repositori.usu.ac.id/bitstream/handl e/123456789/19432/130902043.pdf?sequ ence $=1 \&$ isAllowed $=\mathrm{y}$

2. Anggraheni DA. Fenomena Perceraian: Makna Kebahagiaan dalam Sudut Pandang Single Mother. Semin ASEAN 2nd Psychol Humanit. Published online 2016:122-127.

3. Qaimi DA. Peran Ganda Ibu Dalam Mendidik Anak. Cahaya; 2003.

4. Suprihatin T. Dampak Pola Asuh Orang Tua Tunggal (Single Parent Parenting) Terhadap Perkembangan Remaja. In: Prosiding Seminar Nasional Psikologi Unissula: Penguatan Keluarga Di Zaman Now. Fakultas Psikologi Universitas Islam Sultan Agung; 2018:145-160. 
5. Hasanah U. Pengaruh Perceraian Orangtua Bagi Psikologis Anak. AGENDA $J$ Anal Gend dan Agama. 2019;2(1):18-24. doi:10.31958/AGENDA.V2I1.1983

6. Palupi TN. Tingkat Stres Ibu Dalam Mendampingi Siswa-Siswi Sekolah Dasar Selama Belajar Di Rumah Pada Masa Pandemi Covid-19. Jp3Sdm. 2021;10(1):36-48.

7. Lazzarus RS, Folkman S. Stress Appraisal and Coping. Springer Publishing Company; 1984.

8. Nabit YP, Abdy Keraf MKP, Anakaka DL. Strategi Coping Stres pada Ibu Single Parent Pasca Ditinggal Suami Merantau. $J$ Heal Behav Sci. 2019;1(4):241-261.
9. Sugiyono. Metode Penelitian Kualitatif. Alfabet; 2020.

10. Emzir. Metodologi Penelitian Kualitatif Analisis Data. Rajawali press; 2010.

11. Rahayu AS. Kehidupan Sosial Ekonomi Single Mother dalam Ranah Domestik dan Publik. J Anal Sosiol. 2017;6(1):8299. doi:10.20961/JAS.V6I1.18142

12. Fahriza MR, Ulfa L. Faktor Penyebab Stress dan Dampak Bagi Kesehatan. 2019;15(1):1-4. doi:10.31219/OSF.IO/H4CNV 